\title{
Physicochemical and sensory \\ characterization of meat from lambs \\ subjected to feeding restrictions
}

\section{Caracterizações físico-química e sensorial da carne de cordeiros submetidos a restrições alimentares}

\author{
Marta Suely Madruga1* (D), Narciza Maria de Oliveira Arcanjo', \\ Taliana Kênia Alves Bezerra ${ }^{1}$, Angela Lima Menezes de Queiroz ${ }^{1}$, \\ Katiuscia Menezes Lobo Pimentel ${ }^{1}$, Rita de Cássia Ramos do Egypto Queiroga ${ }^{1}$, \\ Ana Sancha Malveira Batista ${ }^{2}$, Ingrid Conceição Dantas Guerra ${ }^{1}$ \\ Rafaella de Paula Paseto Fernandes ${ }^{1}$ (1), José Morais Pereira Filho ${ }^{3}$, \\ Aderbal Marcos de Azevedo Silva ${ }^{3}$
}

${ }^{1}$ Universidade Federal da Paraíba (UFPB), Programa de Pós-graduação em Ciência e Tecnologia de Alimentos (PPGCTA), João Pessoa/PB - Brasil

2Universidade Estadual Vale do Acaraú, Coordenação de Zootecnia, Sobral/CE - Brasil

${ }^{3}$ Universidade Federal de Campina Grande (UFCG), Departamento de Medicina Veterinária, Patos/PB, Brasil

${ }^{*}$ Corresponding Author: Marta Suely Madruga, Universidade Federal da Paraíba (UFPB), Centro de Tecnologia, Departamento de Tecnologia Química e Alimentos, Laboratório de Análise Química de Alimentos (LAQA),

Laboratório de Análise de Flavour (LAF), Campus I - Cidade Universitária s/ nº, Castelo Branco, CEP: 58059-900,

João Pessoa/PB - Brasil, e-mail: msmadruga@pq.cnpq.br

Cite as: Madruga, M. S., Arcanjo, N. M. O., Bezerra, T. K. A., Queiroz, A. L. M., Pimentel, K. M. L., Queiroga, R. C

R. E., Batista, A. S. M., Guerra, I. C. D., Fernandes, R. P. P., Pereira Filho, J. M., \& Silva, A. M. A. (2020).

Physicochemical and sensory characterization of meat from lambs subjected to feeding restrictions. Brazilian

Journal of Food Technology, 23, e2019264. https://doi.org/10.1590/1981-6723.26419

\begin{abstract}
This study aimed to evaluate the physicochemical and sensory properties of the meat of Santa Ines lambs subjected to quantitative nutrient restrictions. Twenty-four confined animals received diets with $30 \%$ and $60 \%$ feeding restriction levels, and were compared to a controlled group without feeding restrictions (ad libitum). After slaughter, the Longissimus thoracis et lumborum (LTL) muscle was collected for the evaluation, being the lamb meat was affected by the feeding restrictions $(p<0.05)$. The lipid content decreased with the increased restriction, whereas the shear strength, the lightness $\left(L^{\star}\right)$ and the red index $\left(\mathrm{a}^{\star}\right)$ were lower in lambs treated with the $60 \%$ restriction and there were significant variation $(p<0.05)$ in the sensory properties according to diet. Due to the greater score in relation to aroma and similarity to control with respect to flavor, tenderness and overall evaluation, the $30 \%$ feeding restriction level can be considered an economic and efficient alternative for the maintenance of quality in lamb meat.
\end{abstract}

Keywords: Performance; Diet; Nutrition; Lipid profile; Production; Sensory properties.

\section{Resumo}

O objetivo deste estudo foi avaliar as propriedades físico-química e sensorial da carne de cordeiros Santa Inês submetidos a restrições quantitativas de nutrientes. Vinte e quatro animais confinados receberam dietas com $30 \%$ e $60 \%$ de restrição alimentar e foram comparados ao grupo controle sem restrição alimentar (ad libitum). Após o 
abate, o músculo Longissimus thoracis et lumborum (LTL) foi coletado para avaliação, tendo sido a carne de cordeiro afetada pelas restrições alimentares $(p<0,05)$. O conteúdo lipídico diminuiu com o aumento da restrição, enquanto a resistência ao cisalhamento, a luminosidade $\left(L^{*}\right)$ e o índice de vermelho $\left(a^{*}\right)$ foram menores nos cordeiros tratados com $60 \%$ de restrição e houve variação significativa $(p<0,05)$ nas propriedades sensoriais de acordo com a dieta. Em razão do maior escore quanto ao aroma e à similaridade ao controle em relação ao sabor, à maciez e à avaliação global, o nível de restrição alimentar de $30 \%$ pode ser considerado uma alternativa econômica e eficiente para a manutenção da qualidade da carne de cordeiro.

Palavras-chave: Desempenho; Dieta; Nutrição; Perfil lipídico; Produção; Propriedades sensoriais.

\section{Introduction}

The lamb industry represents an excellent opportunity to increase the profitability of rural properties, especially concerning the production of meat lambs. Lamb meat is considered highly nutritious and easily digestible. It is highly valued for its chemical composition, which makes it suitable for human consumption (Nuernberg et al., 2008).

In Brazil, the consumer market is increasingly demanding in relation to the qualitative characteristics of lamb meat, especially its nutritional composition. The market trend favors increased consumption, which it is still extremely low (approximately $0.7 \mathrm{~kg}$ per capita annual consumption) (Fernandes et al., 2012).

In the Brazilian production system, sheep have a great capacity to climate adaptation. This characteristic, along with the great production potential of pastures, can promote increased domestic and export production, thereby serving the interests of the producer and meeting the current demands (Fernandes et al., 2013).

Commercialization occurs predominantly in the form of commercial cuts (Firetti et al., 2018). In this context, the production of meat largely depends on the growth and development of the animals, which results in the growth of body tissues (Cunha et al., 2008). As the physiological maturity of the animal approaches, the rate of muscle deposition decreases and fat increases. The increase in fat generally occurs as an accumulation of visceral fat, which is a product with little commercial value (Dutta et al., 2008).

The tissues develop in a specific sequence, beginning with the nervous tissue, followed with bones and muscles, and, finally, the adipose tissue (fat). From birth to puberty, the growth rate of muscle tissue is greater than the rates of bone and adipose tissue, whereas after puberty to maturity the growth of adipose tissue predominates. That is, as the physiological maturity of the animal approaches, the rate of muscle deposition decreases and fat increases. The adipose tissue is the last to be deposited, with more accentuated growth after puberty, when the muscular growth begins to diminish. The fat presents four distinct areas of deposition, according to the follow sequence: first, the abdominal fat, renal-iguinal and pelvic; second, the intermuscular, then subcutaneous or coverage, and finally intramuscular or marbled. At maturity the muscle growth it is zero, or rather, it is the moment when the muscle mass reaches the maximum peak, where the weight gain is composed only of fat implying in higher food consumption and consequently higher costs (Owens et al., 1995).

Fat is the component with the greatest variation in the carcass and is directly associated with quality of the meat, because it is related to the proportion of muscle. Several factors influence the tissue composition; for instance, diet is an important because productivity is influenced by the quality and quantity of the nutrients consumed (Dutta et al., 2008; Cartaxo et al., 2011).

The semi-arid region of northeastern Brazil suffers periods of severe drought. This phenomenon has caused significant losses in rural production, especially in sheep and goat farming, which are the main livestock activities in the region. Food and water shortages are caused by low and irregular rainfall, which reduces forage production. The drought polygon of Brazil consists of the municipalities most affected by drought in the semiarid region of the country. In this region, the mean annual rainfall is less than $800 \mathrm{~mm}$ 
(Superintendência do Desenvolvimento do Nordeste, 2011), which is a value considered low for livestock production. Because of the low quality and quantity of forage in the dry season, alternatives that can assist livestock production without raising cost have been the focus of agents involved in the lamb industry. The increased demand for ingredients to compose diets formulated for the various categories of animals in the lamb industry points to a growing demand for diets that enable high animal performance and low cost under intensive production systems to maintain a regular supply of meat to the market throughout the year (Cunha et al., 2008).

Among the animal nutrition alternatives, food restriction is an interesting tool that has shown favorable results for cost savings in meat production (Andersen et al., 2005). This alternative reduces the amount of body fat and reduces costs because feed is the most expensive item in meat production (Mushi et al., 2008; Homem Júnior et al., 2010). However, Verbeek et al. (2011) warned that prolonged or severe food restriction could trigger the subjective state of hunger and consequently potentially reduce the animal's welfare.

Andersen et al. (2005), Fernandes et al. (2011) and Verbeek et al. (2011) emphasize that the feeding system becomes the main component of the production cost due to the difficulty of maintaining quality pastures and the use of grains in concentrated supplements. Thus, the feeding system is limited by economic considerations. It is necessary to assess the appropriate amount of food needed to provide nutritional support to the animals, while meeting their nutritional requirements and considering the bioavailability of nutrients in the region to ensure the best performance indexes with positive effects on carcass yield. In this context, this study aimed to assess the effect of feeding restrictions at multiple levels on the quality of meat from Santa Inês lambs with respect to its physical, chemical and sensory aspects.

\section{Materials and methods}

\subsection{Animals and diet}

The experiment was conducted at the Center for Health and Rural Technology (Centro de Saúde e Tecnologia Rural - CSTR) of the Federal University of Campina Grande (Universidade Federal de Campina Grande - UFCG), Patos Campus, located in the Sertão Paraibano (Paraíba Hinterlands) mesoregion at $7^{\circ} 0^{\prime} 28^{\prime \prime} \mathrm{S}$ latitude and $37^{\circ} 16^{\prime} 48^{\prime \prime} \mathrm{W}$ longitude, and altitude of $242 \mathrm{~m}$ above sea level. The regional climate is BSh (semiarid) type and is hot and dry with winter rains. The annual rainfall varies from 400 to $800 \mathrm{~mm}$, with a mean annual temperature of $28.5{ }^{\circ} \mathrm{C}$, maximum temperature of $37{ }^{\circ} \mathrm{C}$ and minimum of $26{ }^{\circ} \mathrm{C}$ (City Brazil, 2013). The mean annual relative air humidity is $61 \%$.

To conduct the study, 24 intact male Santa Inês lambs between the ages of 6 and 7 months were selected after reaching a live weight of $30 \mathrm{~kg}$. The animals were distributed into three groups of eight animals with homogenous weights and were subjected to an initial 10-day period of adaptation to the diets. Then, the lambs began to receive the treatments as follows: no feeding restriction (NR), $30 \%$ feeding restriction and $60 \%$ feeding restriction. The highest feeding restriction level chosen was based on the maintenance needs of the animals according to the National Research Council (2007).

The animals received a complete feed consisting of $45 \%$ elephant grass hay (Pennisetum purpurreum) and $55 \%$ concentrate containing soybean meal, ground corn, calcitic lime, dicalcium phosphate, and mineral salt (Table 1). The diet met the sheep nutritional requirements for animals within the 30 to $45 \mathrm{~kg}$ range, with an average daily gain of $250 \mathrm{~g} \mathrm{day}^{-1}$ based on the NRC requirements (National Research Council, 2007). 
Table 1. Ingredients and chemical composition of the diet used for the feeding of Santa Inês lambs.

\begin{tabular}{|c|c|}
\hline Ingredients & g/kg dry matter \\
\hline Soybean meal & 235.0 \\
\hline Ground corn & 289.9 \\
\hline Elephant grass hay (Pennisetum purpureum) & 450.0 \\
\hline Calcitic lime & 11.9 \\
\hline Dicalcium phosphate & 3.2 \\
\hline Commercial mineral salt $^{1}$ & 10.0 \\
\hline Chemical composition & $(\mathrm{g} / \mathrm{kg})$ \\
\hline Dry matter $^{2}$ & 928.7 \\
\hline Mineral matter & 80.1 \\
\hline Crude protein & 146.4 \\
\hline Ether extract & 33.9 \\
\hline Neutral detergent fiber ${ }^{3}$ & 458.4 \\
\hline Acid detergent fiber & 339.6 \\
\hline Non-fibrous carbohydrates & 308.9 \\
\hline Metabolizable energy (Mcal $/ \mathrm{kg}$ of dry matter) ${ }^{4}$ & 1.89 \\
\hline
\end{tabular}

The animals were weighed (initial weight - IW) upon entering the experimental period. The amount of feed provided and the feed leftover were also weighed to determine the daily consumption. The intake of organic material (IOM) was calculated by subtracting the dry matter from the mineral matter. At the end of 90 days, the animals final weight (FW) was determined prior to slaughter. For the calculation of animal performance, the FW was subtracted from the IW to determine the average weight gain of the animals. This value was related to the number of days to determine the average daily weight gain (ADG). Prior to slaughter, the animals were subjected to 24 and 16 hours of solid and liquid fasting, respectively, and were weighed to obtain the slaughter body weight (SBW).

The slaughter was performed through stunning and bleeding by cutting the carotid artery and jugular vein, followed by skinning and the removal of the viscera (Brasil, 2017). The hot carcass weight was divided by the slaughter body weight, and the result was multiplied by 100 to obtain the hot carcass yield (HCY). Next, the carcasses were refrigerated $\left(3 \pm 2{ }^{\circ} \mathrm{C}\right.$ for 24 hours) and then dissected to obtain the Longissimus thoracis et lumborum (LTL) muscle, of the both sides of the carcasses. The muscles were individually packaged in polyethylene bags under a vacuum, labeled and stored in a freezer at $-20{ }^{\circ} \mathrm{C} \pm 1{ }^{\circ} \mathrm{C}$ prior to analysis. The maximum storage period was four months. All analyses were performed in triplicate.

\subsection{Analysis of meat quality}

\subsubsection{Sample preparation}

The Longissimus thoracis et lumborum (LTL) muscle was thawed under refrigeration $\left(4^{\circ} \mathrm{C}\right)$ for 24 hours. Then, $3 / 4$ cranial part of the muscle was reserved for the determinations of color $\left(\mathrm{L}^{*}, \mathrm{a}^{*}\right.$, and $\left.\mathrm{b}^{*}\right)$ and shear force (SF) and the sensory evaluation. The remainder was ground in a domestic food processor (RI7620, Philips Walita, Brazil) for the analysis of chemical composition, fatty acids, cholesterol, $\mathrm{pH}$, collagen and water-holding capacity (WHC).

\subsubsection{Physicochemical analysis}

The color determination analysis was made using a portable colorimeter (Minolta Chromameter CR-200) and the $\mathrm{L}^{*}, \mathrm{a}^{*}$ and $\mathrm{b}^{*}$ scale of the CIELab evaluation system. Firstly, the samples were exposed to room air; 
after 30 minutes, readings were taken at three different surface points perpendicular to the cross-section avoiding areas with connective tissue or intramuscular fat (Commission Internationale de l'Eclairage, 1978).

To determine the shear force (SF), the meat was grilled (Gran Master Gourmet, Brand ECO) at $180{ }^{\circ} \mathrm{C}$ until internal temperature of $72^{\circ} \mathrm{C}$ (geometric center) for 8 minutes (Fernandes et al., 2012). The temperature monitoring was performed individually using thermocouples connected to a temperature indicator (Brand Gulton). After, the samples were refrigerated $\left(2\right.$ to $5{ }^{\circ} \mathrm{C}$ ) for 24 hours and then were cut in cubes of $2 \mathrm{~cm}^{2}$, in parallel to the muscle fibers, avoiding nerves and fat. The external parts of the steaks were removed.

The SF was measured cutting perpendicularly to fiber the grilled meat cubes with a Texturometer (model TAXT2i, Stable Micro System) coupled to a Warner-Bratzler blade operating at $1.27 \mathrm{~cm} / \mathrm{min}$ according to the methodology of Duckett et al. (1998). The results were expressed in N/cm².

Moisture, ash and meat protein contents were determined according to the analytical procedures described in items no. 950.46.41, 920.153, and 928.08 of the Association of Official Analytical Chemists (2000). Total lipids were quantified by extraction in a mixture of chloroform and methanol according to the method described by Folch et al. (1957). The total collagen content was determined from of the conversion of hydroxyproline, following the methodology described by AOAC 990.26 (Association of Official Analytical Chemists, 2006), and the results were expressed in $\mathrm{g} / 100 \mathrm{~g}$.

The water activity was determined through of the method 978.18, according Association of Official Analytical Chemists (2000) utilizing a Hygrometer (Decagon Devices, AQUALAB CX-2, Washington, EUA).

To assess the WHC, the samples were subjected to a pressure of $49.03 \mathrm{~N} / \mathrm{cm}^{2}$ for a period of five minutes according to the method of Sierra (1973), being calculated for weight difference estimating of drip loss. The $\mathrm{pH}$ measurements were made using a pH meter (PS-2, Digimed, São Paulo, Brazil) with a combined electrode for readings in triplicate with perforation of the meat following method 947.05 (Association of Official Analytical Chemists, 2000).

\subsubsection{Fatty acid analysis}

Fatty acids were measured using the lipid extract obtained based on the methodology of Folch et al. (1957), which was subjected to methylation (Hartman \& Lago, 1973). The fatty acid esters were identified and quantified by gas chromatography (Varian 430-GC, CA, USA) coupled with a flame ionization detector. The separation occurred in a fused silica capillary column (Varian CP WAX 52 CB - dimensions: $60 \mathrm{~m} \times 0.25 \mathrm{~mm}$ and $0.25 \mu \mathrm{m}$ film thickness) using helium as the carrier gas (flow rate of $1 \mathrm{~mL} / \mathrm{min}$ ). The initial and final temperatures of the column were 100 and $240{ }^{\circ} \mathrm{C}$, respectively, with a temperature rise increment rate of $2.5^{\circ} \mathrm{C}$ per minute and holding at the maximum temperature for 20 minutes. The temperature of the detector was held at $260{ }^{\circ} \mathrm{C}$. The methyl ester samples $(1.0 \mu \mathrm{L})$ were injected into a split/splitless injector at $250^{\circ} \mathrm{C}$, and the chromatograms were recorded using the Galaxie Chromatography Data System program. The fatty acid results were obtained by normalizing the areas of the methyl ester. Thus, the results were expressed as the percent area (\%), according the retention times in comparison to the authenticate standards. After quantification, the results were classified as saturated, monounsaturated and polyunsaturated fatty acids.

\subsubsection{Sensory analysis}

To conduct the sensory analysis, the research project was initially submitted to the Research Ethics Committee of the Center of Health of the Federal University of Paraíba (Universidade Federal da Paraíba UFPB) and approved under protocol number 86009 recognized by the National Committee for Ethics in Research (CONEP). 
The sensory characteristics of meat samples were determined by Quantitative Descriptive Analysis (QDA) with the participation of trained assessors (Stone \& Sidel, 1998; Faria \& Yotsuyanagi, 2002; Meilgaard et al., 2006). Therefore, were recruited twenty individuals among the students and staff of UFPB based on their appreciation and consumption of lamb, availability to participate and ability to describe proportionality through scales. A questionnaire was answered containing questions related to the consumption of lamb meat aiming the descriptive analysis. Informed Consent forms were provided prior to the analysis. The panel was trained according to ISO standards (International Organization for Standardization, 1993, 2006) and basic odor and taste recognition tests were performed as well as ordination tests using unstructured scales (Dutcosky, 2011).

We used the triangular test to select the assessors with higher sensory acuity. The ability of each individual to discriminate the samples was analyzed through two triangular tests in three sessions, representing the repetitions. The training was completed after verifying the individual skills of the assessors, being selected those with the highest discriminatory power with reproducible results.

Eleven assessors, composed of four men and seven women aged between 20 and 40 years old, were selected to evaluate the sensory profile of meat samples. The $L$. dorsi samples were cooked on an electric grill at $180{ }^{\circ} \mathrm{C}$ until reaches $72^{\circ} \mathrm{C}$ internally (Gran Master Gourmet, Brand ECO), and the temperature monitoring was performed individually using thermocouples connected to a temperature indicator (Brand Gulton). The samples were cut into $2 \mathrm{~cm}^{2}$ cubes and encoded with random three-digit numbers, being the tests were performed in three sessions and evaluated in individual booths lit with white light. At each session, the assessors evaluated the samples on an unstructured nine-cm scale, ranging from 1 to 9 with respect to the intensity of the color, aroma, tenderness, juiciness, flavor and overall evaluation attributes.

\subsection{Statistical analysis}

For statistical analysis, the animals were distributed into three treatments (no feeding restriction - NR, $30 \%$ and $60 \%$ restriction) with eight replications using a completely randomized design. The variables resulting from the physicochemical analyses were subjected to analysis of variance (ANOVA) using the PROC ANOVA procedure. In the case of significant differences, the means were compared using Tukey's test at $5 \%$ probability.

The sensorial assessment data were subjected using the GLM (Generalized Linear Models) routine with the treatments included in the model. The means were compared using the Ryan-Einot-Gabriel-Welsch test at 5\% probability in SAS (Statistical Analysis System Institute, 2001) considering the following Mathematical Model 1:

$\mathrm{Y}_{\mathrm{ijk}}=\mu+\mathrm{D}_{\mathrm{ijk}}+\mathrm{e}_{\mathrm{ijk}}$

where: $Y_{i j k}=$ observed value of each animal characteristic; $\mu=$ overall mean effect; $D_{i j k}=$ diet effect; and $\mathrm{e}_{\mathrm{ijk}}=$ random error.

\section{Results and discussion}

The quantitative restriction of nutrients significantly affected the performance parameters of the Santa Inês lamb (Table 2). We observed a decrease in the FW, ADG, IOM, and SBW values with increasing food restrictions. This is a result of the slower tissue development due to the low energy density intake provided by the diet (Araújo Filho, 2012).

Table 2. Performance of lambs in confinement subjected to diets with different levels of feeding restrictions (mean \pm standard deviation).

\begin{tabular}{cccc}
\hline Variable & Without restriction & $\mathbf{3 0 \%}$ restriction & 60\% restriction \\
\hline $\mathrm{IW}^{1}(\mathrm{~kg})$ & $31.84^{\mathrm{a}} \pm 3.42$ & $31.58^{\mathrm{a}} \pm 3.42$ & $31.70^{\mathrm{a}} \pm 1.82$ \\
\hline $\mathrm{FW}^{2}(\mathrm{~kg})$ & $45.19^{\mathrm{a}} \pm 1.46$ & $39.31^{\mathrm{b}} \pm 1.70$ & $32.32^{\mathrm{c}} \pm 2.21$ \\
\hline $\mathrm{ADG}^{3}(\mathrm{~g})$ & $248.00^{\mathrm{a}} \pm 35.12$ & $133.00^{\mathrm{b}} \pm 37.48$ & $20.00^{\mathrm{c}} \pm 5.80$ \\
\hline $\mathrm{IOM}^{4}(\mathrm{~g} / \mathrm{day})$ & $1350.00^{\mathrm{a}} \pm 148.5$ & $928.00^{\mathrm{b}} \pm 98.4$ & $543.00^{\mathrm{c}} \pm 112.40$ \\
\hline $\mathrm{SBW}^{5}(\mathrm{~kg})$ & $42.82^{\mathrm{a}} \pm 1.31$ & $37.80^{\mathrm{b}} \pm 2.04$ & $31.10^{\mathrm{c}} \pm 2.20$ \\
\hline $\mathrm{HCY}^{6}(\%)$ & $50.80^{\mathrm{a}} \pm 0.96$ & $49.30^{\mathrm{a}} \pm 0.84$ & $50.10^{\mathrm{a}} \pm 1.01$ \\
\hline
\end{tabular}

${ }^{1}$ Initial Weight. ${ }^{2}$ Final weight. ${ }^{3}$ Average daily gain. ${ }^{4}$ Intake of organic material. ${ }^{5}$ Slaughter body weight. ${ }^{6}$ Hot carcass yield. Mean values in the same row not followed by a common letter significantly differ (Tukey, $p<0.05$ ). Source: Araújo Filho (2012). 
The weight of the animals decreased in accordance with the increasing percentage of the feeding restriction, resulting in meat with a low fat content. Thus, the ADG ranged from 20 to $248 \mathrm{~g}$. The animals under no feeding restriction (NR) performed better because the SBW directly reflected the reduction in intake. Lower SBW values were observed for the animals subjected to the $30 \%$ and $60 \%$ restrictions $(p<0.05)$ as result of the IOM, which was highest in the NR treatment. However, the HCY was not affected $(p>0.05)$, indicating that there was no influence warm carcass yield, even with the reduction of the final weight of the animal to be slaughtered according to the feeding restriction. This important tool could reduce the cost of production. The quality of carcass did not depend only on animal weight, but also on the muscle quantity, fat degree, conformation and aged, being that classification criterion based only on inconsistent weights (Rodrigues et al., 2006).

In terms of the lamb meat quality (Table 3$)$, the feeding restriction affected $(p<0.05)$ the lightness $\left(\mathrm{L}^{*}\right)$, red index, shear force (SF), lipid content, and medium and long chain fatty acid content parameters. The intensity of L*, red index, SF and long chain fatty acid content were higher in animals under feeding restrictions, although a smaller lipid percentage was observed in meat from animals under the $60 \%$ restriction $(p<0.05)$.

Table 3. Physicochemical characteristics of meat from lambs subjected to a diet with feeding restrictions (mean \pm standard deviation).

\begin{tabular}{|c|c|c|c|}
\hline \multirow[b]{2}{*}{ Variable } & \multicolumn{3}{|c|}{ Treatments } \\
\hline & $\begin{array}{c}\text { Without } \\
\text { restriction }\end{array}$ & $\begin{array}{c}30 \% \\
\text { restriction }\end{array}$ & $\begin{array}{c}60 \% \\
\text { restriction }\end{array}$ \\
\hline $\mathrm{L}^{* 1}$ & $39.26^{\mathrm{b}} \pm 0.73$ & $41.51^{\mathrm{ab}} \pm 0.81$ & $43.09^{\mathrm{a}} \pm 0.78$ \\
\hline$a^{* 2}$ & $15.40^{\mathrm{b}} \pm 0.58$ & $17.16^{\mathrm{a}} \pm 0.41$ & $17.62^{\mathrm{a}} \pm 0.44$ \\
\hline$b^{* 3}$ & $8.19^{a} \pm 0.55$ & $9.10^{\mathrm{a}} \pm 0.47$ & $7.61^{\mathrm{a}} \pm 0.47$ \\
\hline $\mathrm{WHC}^{4}(\%)$ & $73.78^{a} \pm 0.85$ & $73.19^{a} \pm 1.24$ & $72.96^{\mathrm{a}} \pm 1.46$ \\
\hline $\mathrm{pH}$ & $5.97^{\mathrm{a}} \pm 0.07$ & $6.04^{a} \pm 0.08$ & $6.03^{a} \pm 0.09$ \\
\hline $\mathrm{SF}^{5}\left(\mathrm{~N} / \mathrm{cm}^{2}\right)$ & $23.94^{\mathrm{a}} \pm 0.20$ & $30.40^{\mathrm{ab}} \pm 0.20$ & $34.23^{b} \pm 0.26$ \\
\hline $\mathrm{Wa}^{6}$ & $0.98^{\mathrm{a}} \pm 0.01$ & $0.98^{\mathrm{a}} \pm 0.00$ & $0.97^{\mathrm{a}} \pm 0.00$ \\
\hline Moisture (g/100 g) & $72.09^{a} \pm 0.65$ & $72.60^{\mathrm{a}} \pm 0.20$ & $73.13^{\mathrm{a}} \pm 0.40$ \\
\hline $\operatorname{Ash}(\mathrm{g} / 100 \mathrm{~g})$ & $1.01^{\mathrm{a}} \pm 0.02$ & $1.05^{\mathrm{a}} \pm 0.01$ & $1.03^{\mathrm{a}} \pm 0.02$ \\
\hline Proteins $(\mathrm{g} / 100 \mathrm{~g})$ & $23.23^{a} \pm 0.72$ & $22.23^{a} \pm 0.74$ & $23.74^{\mathrm{a}} \pm 1.05$ \\
\hline Collagen $(\mathrm{g} / 100 \mathrm{~g})$ & $0.53^{a} \pm 0.12$ & $0.75^{a} \pm 0.18$ & $0.45^{\mathrm{a}} \pm 0.03$ \\
\hline Lipids (g/100 g) & $5.16^{\mathrm{a}} \pm 0.37$ & $4.59^{a} \pm 0.27$ & $3.19^{b} \pm 0.37$ \\
\hline SFA $^{7}$ & $0.40^{\mathrm{a}} \pm 0.10$ & $0.35^{\mathrm{a}} \pm 0.05$ & $0.31^{\mathrm{a}} \pm 0.11$ \\
\hline MUFA $^{8}$ & $4.48^{\mathrm{a}} \pm 0.84$ & $3.43^{b} \pm 0.48$ & $3.66^{\mathrm{b}} \pm 0.36$ \\
\hline PUFA $^{9}$ & $95.08^{b} \pm 0.96$ & $96.18^{a} \pm 0.50$ & $95.98^{\mathrm{a}} \pm 0.41$ \\
\hline
\end{tabular}

${ }^{1}$ Lightness. ${ }^{2}$ Intensity of the color red. ${ }^{3}$ Intensity of the color yellow. ${ }^{4}$ Water holding capacity. ${ }^{5}$ Shear force. ${ }^{6}$ Water activity. ${ }^{7}$ Saturated fatty acid (C4 a C9). ${ }^{8}$ Monoinsaturated fatty acid (C10:0-C15:1). ${ }^{9}$ Poliinsaturated chain fatty acid (C16:0-C24:0). Mean values in the same row not followed by a common letter significantly differ (Tukey, $p<0.05$ ).

The meat of animals under the $60 \%$ feeding restriction showed higher lightness (L*) intensity, which differed from that of the animals not under a feeding restriction. This behavior can be justified by the lower fat content that makes the meat lighter. The fat implies loss of capillary permeability, which difficulty the transfer of oxygen from the muscle fiber, requiring a greater contribution of myoglobin to oxygen storage, reducing the luminosity (Sousa et al., 2016).

Studies have reported lightness values >30 for lamb meat (Madruga et al., 2008; Fernandes et al., 2012). We reproduced these results with lightness ranging from 39.26 to 43.09 . The meat of the animals subjected to 30 to $60 \%$ feeding restrictions showed no differences in lightness and red index, although a larger a* value was observed for these treatments when compared to meat from the animals fed ad libitum (NR). The $a^{*}$ values for the NR treatment were similar to those described by Costa et al. (2009) when evaluating lamb meat from the same breed subjected to diets with different fiber contents $\left(a^{*}=14.73\right)$. 
The meat from animals subjected to the $60 \%$ restriction was considered lean $(3.19 \mathrm{~g} / 100 \mathrm{~g})$ when compared to the other animals, which may be attributed to the lower accumulation of intramuscular and intermuscular fat because the animals in this group had lower final weights at slaughter. Fat is considered an important fraction because it influences the visual aspect and the edible portion and has a direct influence on the quality of meat by contributing to both nutritional and sensory characteristics; however, its excess can reduce the lean meat yield (Fontenele et al., 2010).

For all treatments, the lipid content was higher than that obtained by Freire et al. (2010), who evaluated the lipid content of meat from Santa Inês lambs in the same weight range. In a study on food restriction and refeeding in lambs, Savary-Auzeloux et al. (2008) observed that an inappropriate feeding level after nutritional stress might have consequences for the animal's capacity to cope with future oxidative processes as well as the oxidation level of the meat components during meat maturation. In contrast, the results corroborated the findings of Almeida Júnior et al. (2004) and Fontenele et al. (2010), who stated that the percentage of fat deposited between and within the cells of the Longissimus thoracis et lumborum (LTL) muscle might be an important indication of the percentage of intramuscular fat in the carcass. Consequently, there was a significant difference in relation to percentage of lipids among the treatments (Table 3), indicating that the food restriction reduces fat and minimizes cost.

In the present study, the SF values obtained for the meat from lambs under NR and subjected to a $30 \%$ restriction were similar $\left(23.94 \mathrm{~N} / \mathrm{cm}^{2}\right.$ and $30.40 \mathrm{~N} / \mathrm{cm}^{2}$, respectively), whereas compared to that of the control group, the $60 \%$ restriction group resulted in tougher meat with a SF $34.23 \mathrm{~N} / \mathrm{cm}^{2}(p<0.05)$. This difference may be related to the low lipid content in the meat. The observed SF values were inferior to those obtained by Costa et al. (2009) for meat from Santa Ines lambs slaughtered with similar weight ranges (45 kg). This pattern may be explained by the influence of feeding management on the amount of fat deposited (Geraseev et al., 2007). The relationship between the effect of feeding restriction on the fat content and SF of the lamb meat may be attributed to the accumulation of intramuscular and intermuscular fat. Animals subjected to moderate feeding restrictions (in this case 30\%) showed final slaughter weights similar to the group under no feeding restriction, whereas the $60 \%$ restriction group had a lower ADG compared to these two groups.

The results obtained for medium-chain fatty acids (MCFA) were the inverse of those obtained for long chain fatty acids (LCFA), with a decrease and increase of the chains observed in the meat of animals subjected to restricted intake, respectively.

Therefore, the fatty acid profile undergoes variations depending on the diet because lamb meat has higher concentrations of saturated fatty acids (Fernandes et al., 2014) and a low ratio of polyunsaturated:saturated fatty acids. Madruga et al. (2005) reported a tendency towards the predominance of palmitic (C16:0), stearic (C18:0) and oleic (18:1) acids when investigating the effects of the diet on meat quality of Santa Inês lambs.

An interesting result was the uniformity of the observed $\mathrm{pH}$ values, which did not differ among treatments $(p>0.05)$. Generally, the nutritional status influences the $\mathrm{pH}$ of the meat too. In this study (Sousa et al., 2016), the animals subjected to a $60 \%$ restriction showed no increase in $\mathrm{pH}$, indicating that this restriction probably did not take the animals to a state of malnutrition due to the short restriction period (60 days) to which the animals were subjected. Malnutrition in sheeps is one of the primary causes of elevated $\mathrm{pH}$ in meat because it prevents sufficient accumulation of glycogen reserves in the muscles, thereby reducing the formation of lactic acid and preventing the $\mathrm{pH}$ from declining normally (Madruga et al., 2008).

After the bleeding process, in the absence of oxygen, muscle glycogen becomes the energy source for contraction through the anaerobic glycolytic pathway. Glycogen is transformed into glucose and through of the process of glycolysis is consumed, generating lactic acid that accumulates in muscle tissue, causing the $\mathrm{pH}$ to be reduced from 7 to 7.2 to a range between 5.5 to 5.8 after 24 hours of the slaughter. When the $\mathrm{pH}$ reaches these values, enzymatic inhibition occurs and the anaerobic glycolysis process is paralyzed. According to the results shown in the Table 3, due to $\mathrm{pH}$ values between 5.97 and 6.04, probably occurred a 
higher muscle glycogen consumption before slaughter, making it difficult the $\mathrm{pH}$ decrease, developing a DFD meat (dark, firm and dry). Higher the $\mathrm{pH}$ value can affect the color, appearance, taste, aroma, texture and water holding capacity (WHC) of the meat. In addition to the speed of $\mathrm{pH}$ drop, muscle temperature is also very important. If the carcass is cooled too fast with a $\mathrm{pH}$ above 6.0 , before rigor mortis is completed, muscle fiber shortening occurs, decreasing sarcomere size and reducing softness and water retention capacity (Jimenez Filho, 2012).

According to the results presented in Table 3, there was a significant difference between the color and texture results. However, as the samples did not presented significant variations relation to the $\mathrm{pH}$, remaining between 5.97 and 6.04 in the three treatments, was considered only the influence of the type of quantitative restriction applied according to the treatment. Thus, probably these differences are not related to the high $\mathrm{pH}$ values detected, because were consider the same conditions of $\mathrm{pH}$ and in the moment of the analyses.

The absence of a significant difference $(p>0.05)$ in the protein content (between 22.23 and $23.74 \mathrm{~g} / 100 \mathrm{~g}$ ) probably resulted from the fact that protein is the component that undergoes the least change in the meat composition after the growth phase (Ortiz et al., 2005).

Under feeding restrictions, animals tend to exhibit low fat deposition due to the reduction in energy intake. This decrease is reflected weight reduction of the organs compared to the weight of the empty carcass. Thus, with the increase in restriction, the decrease in protein only initiates as an attempt at subsistence if the feed ingested by the animals does not supply the requirements for maintenance.

The collagen content calculated from the hydroxyproline in animals subjected to the three treatments did not differ $(p>0.05)$, reflecting the behavior of the muscle proteins. We observed a trend of increase collagen content in the treatment with restriction of 30\%. Similarly to the studies of Jacques et al. (2017), the collagen content did not influenced for the dietary treatments $(p>0.05)$. Differently, Zhao et al. (2015) observed the collagen content presented an increase in lamb meat that were submitted to feed restriction, but not influencing also the levels of proteins, as the present study.

The sensory evaluation (Figure 1) showed a significant difference $(p<0.05)$ for flavor and aroma, different from Silva et al. (2016) findings, where the restriction did not influence the sensory parameters of meat from Morada Nova sheep.

The scores for the flavor attribute ranged from 4.25 to 5.38, with the highest score attributed to the meat from the NR lambs that showed a higher percentage of fat. The accentuated flavor was presented in the treatment with greater amount of concentrates (without restriction), compared to the animals subject to restrictions. This result is explained by the fact that fat is responsible for attributing flavor and texture to the meat and, therefore, its reduction may affect the overall evaluation of the product. Meat from very lean animals has less intense flavor because the amount of intramuscular fat can directly affect the sensory properties of the meat, producing detectable changes in palatability. This sensory difference, especially in relation to the meat flavor, can be explained by the animals diets, and reflects the differentiated production of volatile fatty acids by rumen microorganisms that in turn alter fat deposition in the muscle tissue (Santos et al., 2013; Rego et al., 2017). The amount of intramuscular fat can affect the sensory properties of the meat by replacing the muscle fiber with fat, producing detectable changes in the palatability of the animals that received food ad libitum. Similarly, meat from animals under the $30 \%$ restriction showed higher scores for aroma $(p<0.05)$.

The color was not affected by feeding restrictions. In this case, we observed that the meat of the animals under feed restriction presented a paler trend according to the increased restriction levels, with values ranging from 3.47 to 4.20 . Thus, higher color scores were attributed to the meat from animals not subjected to feeding restriction, which were considered redder. As for flavor, a higher use score was attributed to an unrestricted diet, probably with higher fat content, which benefits as sensory properties of meat. All samples that were sensorially evaluated were considered to be similar in tenderness and juiciness $(p>0.05)$, presenting a trend of lower values with the increase of the restriction. 


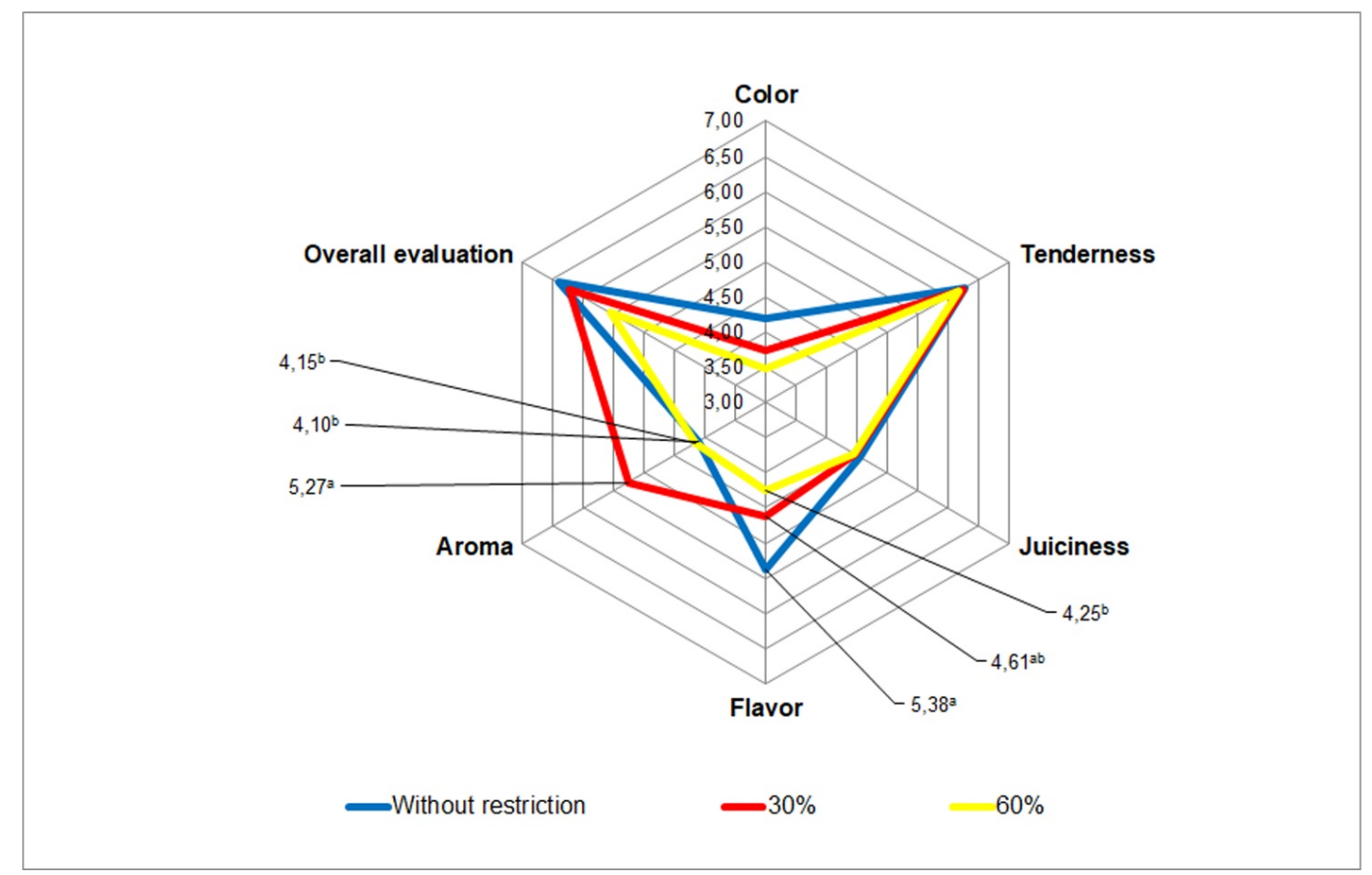

Figure 1. Sensory evaluation of meat from lambs subjected to different diets. Mean values of each attribute not followed by a common letter significantly differ (Tukey, $p<0.05$ ).

This result can be explained by the low SF values, which remained below $4.6 \mathrm{~kg}$ (the value considered acceptable) (Gallo et al., 2019).

Generally, the mean values assigned for the overall evaluation remained above 5 for all samples. The results showed that higher scores were attributed to the meat of animals fed ad libitum (NR) and under the $30 \%$ feeding restriction (6.42 and 6.23 , respectively), whereas those with the $60 \%$ restriction were also considered above average by the sensory panel (5.56). Thus, overall evaluation favors the practice of feeding restriction in production systems because the results obtained for both groups did not present significant differences.

Juiciness was highest in the treatment with the highest level of restriction and tenderness and color did not differ significantly compared to the animals under no feeding restrictions. The other two treatments (ad libitum and $30 \%$ of restriction) showed greater intensity for most attributes, which influence purchase and may make the product unacceptable to consumers (Renerre, 2000).

\section{Conclusion}

Therefore, a feeding restriction of up to $60 \%$ interferes with the lambs' performance but does not affect the hot carcass yield parameters; thus, it is an important tool for the reduction of production costs. The lipid content decreases with the increasing feeding restriction level, whereas the lightness intensity, yellow color $\left(b^{*}\right)$, shear force, flavor, tenderness and overall evaluation of lamb meat were similar between animals subjected to the ad libitum and 30\% restriction diets. The meat from the latter group (30\%) had greater aroma score, estimating higher acceptability. Therefore, a feeding restriction of up to $30 \%$ is an economical alternative for lambs in confinement during periods of drought because it maintains the quality of the meat and feed efficiency similar to animals fed ad libitum. 


\section{Acknowledgements}

The authors thank the Coordination for the Improvement of Higher Education Personnel (CAPES, Brazil) for the financial support.

\section{References}

Almeida Júnior, G. A., Costa, C., Monteiro, A. L. G., Garcia, C. A., Munari, D. P., \& Neres, M. A. (2004). Qualidade da carne de cordeiros criados em creep feeding com silagem de grãos úmidos de milho. Revista Brasileira de Zootecnia, 33(4), 1039-1047. http://dx.doi.org/10.1590/S1516-35982004000400024

Andersen, H. J., Oksbjerg, N., Young, J. F., \& Therkildsen, M. (2005). Feeding and meat quality: A future approach. Meat Science, 70(3), 543-554. PMid:22063752. http://dx.doi.org/10.1016/j.meatsci.2004.07.015

Araújo Filho, J. M. (2012). Desempenho produtivo e exigências de macrominerais em carneiros Santa Inês sob restrição alimentar (Tese de doutorado). Universidade Federal do Ceará, Fortaleza.

Association of Official Analytical Chemists - AOAC. (2000). Official methods of analysis (17th ed.). Gaithersburg: AOAC International.

Association of Official Analytical Chemists - AOAC. (2006). Official methods of analysis (18th ed.). Gaithersburg: AOAC International.

Brasil. (30 mar. 2017). Regulamento da Inspeção Industrial e Sanitária de Produtos de Origem Animal (RIISPOA), $108 f$.

Decreto n. 9.013, de 29 de março de 2017. Regulamenta a Lei n. 1.283, de 18 de dezembro de 1950 , e a lei $n^{\circ} 7.889$, de 23 de novembro de 1989, que dispõem sobre a Inspeção Industrial e Sanitária de Produtos de Origem Animal. Diário Oficial da União, Brasília. Seção 1, p. 3-27.

Cartaxo, F. Q., Sousa, W. H., Costa, R. G., Cezar, M. F., Pereira Filho, J. M., \& Cunha, M. G. G. (2011). Características quantitativas da carcaça de cordeiros de diferentes genótipos submetidos a duas dietas. Revista Brasileira de Zootecnia, 40(10), 2220-2227. http://dx.doi.org/10.1590/S1516-35982011001000023

City Brazil. (2013). Dados gerais do município de Patos-PB. Retrieved in 2018, March 19, from http/l:www.citybrazil.com.br

Commission Internationale de l'Eclairage - CIE. (1978). International commission on illumination, recommendations, on uniform colour spaces, colour difference equations, psychometric colour terms (Suppl. 15, CIE publication, 15 (E-1.3.1) 1971/(TO-1.3)). Paris: Bureau Central de la CIE.

Costa, R. G., Batista, A. S. M., Madruga, M. S., Gonzaga Neto, S., Queiroga, R. C. R. E., Araújo Filho, J. T., \& Villarroel, A. S. (2009). Physical and chemical characterization of lamb meat from different genotypes submitted to diet with different fibre contents. Small Ruminant Research, 81(1), 29-34. http://dx.doi.org/10.1016/j.smallrumres.2008.10.007

Cunha, M. G. G., Carvalho, F. F. R., Gonzaga Neto, S., \& Cezar, M. F. (2008). Características quantitativas de carcaça de ovinos Santa Inês confinados alimentados com rações contendo diferentes níveis de caroço de algodão integral. Revista Brasileira de Zootecnia, 37(6), 1112-1120. http://dx.doi.org/10.1590/S1516-35982008000600023

Duckett, S. K., Klein, T. A., Leckie, R. K., Thorngate, J. H., Busboom, J. R., \& Snowder, G. D. (1998). Effect of freezing on calpastatin activity and tenderness of callipyge lamb. Journal of Animal Science, 76(7), 1869-1874. PMid:9690642. http://dx.doi.org/10.2527/1998.7671869x

Dutcosky, S. D. (2011). Análise sensorial de alimentos (2. ed.). Curitiba: Champagnat.

Dutta, T. K., Agnihotri, M. K., \& Rao, S. B. N. (2008). Effect of supplemental palm oil on nutrient utilization, feeding economics and carcass characteristics in post-weaned Muzafarnagari lambs under feedlot condition. Small Ruminant Research, 78(1-3), 66-73. http://dx.doi.org/10.1016/j.smallrumres.2008.05.002

Faria, E. Z., \& Yotsuyanagi, K. (2002). Técnicas de análise sensorial (1. ed.). Campinas: ITAL.

Fernandes, A. R. M., Orrico Junior, M. A. P., Orrico, A. C. A., Vargas Junior, F. M., \& Oliveira, A. B. M. (2011). Desempenho e características qualitativas da carcaça e da carne de cordeiros terminados em confinamento alimentados com dietas contendo soja grão ou gordura protegida. Revista Brasileira de Zootecnia, 4O(8), 1822-1829. http://dx.doi.org/10.1590/S151635982011000800028

Fernandes, R. P. P., Freire, M. T. A., Carrer, C. C., \& Trindade, M. A. (2013). Evaluation of physicochemical, microbiological and sensory stability of frozen stored vacuum-packed lamb meat. Journal of Integrative Agriculture, 12(11), 1946-1952. http://dx.doi.org/10.1016/S2095-3119(13)60632-2

Fernandes, R. P. P., Freire, M. T. A., Paula, E. S. M., Kanashiro, A. L. S., Catunda, F. A. P., Rosa, A. F., Balieiro, J. C. C., \& Trindade, M. A. (2014). Stability of lamb loin stored under refrigeration and packed in different modified atmosphere packaging systems. Meat Science, 96(1), 554-561. PMid:24018275. http://dx.doi.org/10.1016/j.meatsci.2013.08.005

Fernandes, R. P. P., Freire, M. T. A., Guerra, C. C., Carrer, C. C., Balieiro, J. C. C., \& Trindade, M. A. (2012). Physical and chemical stability microbiological and sensory analysis of vacuum packed sheep meat stored under refrigeration. Ciência Rural, 42(4), 724-729. http://dx.doi.org/10.1590/S0103-84782012000400025

Firetti, R., Alberti, A. L. L., Zundt, M., Santos, A. O., Rego, F. C. A., \& Astolphi, J. L. L. (2018). Sheep meat commercialization in the retail market in Brazilian cities. Revista Brasileira de Zootecnia, 47(e20160354), http://dx.doi.org/10.1590/rbz4720160354

Folch, J., Less, M., \& Stanley, S. (1957). A simple method for the isolation and purification of total lipids from animal tissues. The Journal of Biological Chemistry, 226(1), 497-509. PMid:13428781. 
Fontenele, R. M., Pereira, E. S., Pimentel, P. G., Mizubuti, I. Y., Monte, A. L. S., Candido, M. J. D., Louzada Regadas Filho, J. G., \& Rocha Junior, J. N. (2010). Níveis de energia metabolizável em rações de ovinos Santa Inês: peso dos órgãos internos e do trato digestório. Semina: Ciências Agrárias, 31(4), 1095-1104. http://dx.doi.org/10.5433/1679-0359.2010v31n4p1095

Freire, M. T. A., Nakao, M. Y., Guerra, C. C., Carrer, C. C., Souza, S. C., \& Trindade, M. A. (2010). Determinação de parâmetros físico-químicos e de aceitação sensorial da carne de cordeiros proveniente de diferentes tipos raciais. Alimentos $e$ Nutrição, 21, 481-486.

Gallo, S. B., Arrigoni, M. B., Lemos, A. L. S. C., Haguiwara, M. M. H., \& Bezerra, H. V. A. (2019). Influence of lamb finishing system on animal performance and meat quality. Acta Scientiarum. Animal Sciences, 41, e44742. http://dx.doi.org/10.4025/actascianimsci.v41i1.44742

Geraseev, L. C., Perez, J. R. O., Quintão, F. A., Pedreira, B. C., \& Carvalho, P. A. (2007). Efeito da restrição pré e pós-natal sobre o crescimento dos depósitos de gordura de cordeiros Santa Inês. Arquivo Brasileiro de Medicina Veterinária e Zootecnia, 59(3), 782-788. http://dx.doi.org/10.1590/S0102-09352007000300033

Hartman, L., \& Lago, R. C. A. (1973). Rapid preparation of fatty acid methyl ester from lipids. Laboratory Practice, 22(8), 475476.

Homem Júnior, A. C., Ezequiel, J. M. B., Galati, R. L., Gonçalves, J. S., Santos, V. C., \& Sato, R. A. (2010). Grãos de girassol ou gordura protegida em dietas com alto concentrado e ganho compensatório de cordeiros em confinamento. Revista Brasileira de Zootecnia, 39(3), 563-571. http://dx.doi.org/10.1590/S1516-35982010000300016

International Organization for Standardization - ISO. (1993). ISO 8586-1: Sensory analysis: General guidance for the selection, training and monitoring of assessors. Part 1: Selected assessors. Genéve: ISO.

International Organization for Standardization - ISO. (2006). ISO 5496: Sensory analysis: Methodology: Initiation and training of assessors in the detection and recognition of odours. Genéve: ISO.

Jacques, J., Chouinard, P. Y., Gariépy, C., \& Cinq-Mars, D. (2017). Meat quality, organoleptic characteristics, and fatty acid composition of Dorset lambs fed different forage to concentrate ratios or fresh grass. Canadian Journal of Animal Science, 97 , 290-301.

Jimenez Filho, D. L. (2012). Effect of transport on meat quality: Review. Medicina Veterinaria-Recife, 6, 26-31.

Madruga, M. S., Costa, R. G., Silva, A. M., Marques, A. V. M. S., Cavalcanti, R. N., Narain, N., Albuquerque, C. L., \& Filho, G. E. (2008). Effect of silk flower hay (Calotropis procera Sw) feeding on the physical and chemical quality of Longissimus dorsi muscle of Santa Inez lambs. Meat Science, 78(4), 469-474. PMid:22062467. http://dx.doi.org/10.1016/j.meatsci.2007.07.016

Madruga, M. S., Sousa, W. H., Rosales, M. D., Cunha, M. G. G., \& Ramos, J. L. F. (2005). Qualidade da carne de cordeiros Santa Inês terminados com diferentes dietas. Revista Brasileira de Zootecnia, 34(1), 309-315. http://dx.doi.org/10.1590/S151635982005000100035

Meilgaard, M. C., Civille, G. V., \& Carr, B. T. (2006). Sensory evaluation techniques (4th ed.). Boca Raton: CRC Press. http://dx.doi.org/10.1201/b16452.

Mushi, D. E., Eik, L. O., Thomassen, M. S., Sørheim, O., \& Dnøy, T. (2008). Suitability of Norwegian short-tail lambs, Norwegian dairy goats and Cashmere goats for meat production: Carcass, meat, chemical and sensory characteristics. Meat Science, 80(3), 842-850. PMid:22063606. http://dx.doi.org/10.1016/j.meatsci.2008.03.032

National Research Council - NRC. (2007). Nutrient requirements of small ruminants: Sheep, goats, cervids and new world camelids. Washington:National Academy Press.

Nuernberg, K., Fischer, A., Nuernberg, G., Ender, K., \& Dannenberger, D. (2008). Meat quality and fatty acid composition of lipids in muscle and fatty tissue of Skudde lambs fed grass versus concentrate. Small Ruminant Research, 74(1-3), 279-283. http://dx.doi.org/10.1016/j.smallrumres.2007.07.009

Ortiz, J. S., Costa, C., Garcia, C. A., \& Silveira, L. V. A. (2005). Efeito de diferentes níveis de proteína bruta na ração sobre o desempenho e as características de carcaça de cordeiros terminados em Creep Feeding. Revista Brasileira de Zootecnia, 34(6 suppl), 2390-2398. http://dx.doi.org/10.1590/S1516-35982005000700027

Owens, F. N., Gill, D. R., Secrist, D. S., \& Coleman, S. W. (1995). Review of some aspects of growth and development of feedlot cattle. Journal of Animal Science, 73(10), 3152-3172. http://dx.doi.org/10.2527/1995.73103152x

Rego, F. C. A., Françozo, M. C., Ludovico, A., Castro, F. A. B., Zundt, M., Lupo, C. R., Belan, L., Cunha Filho, L. F. C., Santos, J. S., \& Castilho, C. (2017). Fatty acid profile and lambs' meat quality fed with different levels of crude glycerin replacing corn. Semina: Ciências Agrárias, 38(4), 2051-2064. http://dx.doi.org/10.5433/1679-0359.2017v38n4p2051

Renerre, M. (2000). Review: Biochemical basis of fresh meat color. In Proceedings of the 45th International Congress of Meat Science and Technology (pp. 344-352). Yokohama, Japan: American Meat Science Association.

Rodrigues, S., Cadavez, V., \& Teixeira, A. (2006). Breed and maturity effects on Churra Galega Braganc, ana and Suffolk lamb carcass characteristics: Killing-out proportion and composition. Meat Science, 72(2), 288-293. PMid:22061556. http://dx.doi.org/10.1016/j.meatsci.2005.07.019

Santos, V. C., Ezequiel, J. M. B., Morgado, E. D. S., \& Souza Júnior, S. C. (2013). Carcass and meat traits of lambs fed byproducts from the processing of oil seeds. Acta Scientiarum: Animal Sciences, 35(4), 387-394. http://dx.doi.org/10.4025/actascianimsci.v35i4.20403

Savary-Auzeloux, I., Durand, D., Gruffat, D., Bauchart, D., \& Ortigues-Marty, I. (2008). Food restriction and refeeding in lambs influence muscle antioxidant status. Animal, 2(5), 738-745. PMid:22443599. http://dx.doi.org/10.1017/S1751731108001742

Sierra, I. (1973). Aportación al estudio del cruce Blanco Belga x Landrace: Caracteres productivos: Calidad de la canal y de la carne (Vol. 16, pp. 43). Zaragoza: Instituto de Economía y Producciones Ganaderas del Ebro. 
Silva, A. C. F., Costa, H. H. A., Peres, M. C. R., Costa, A. C., Sousa, D. R., Batista, A. S. M., \& Landim, A. V. (2016). Meat quality of Morada Nova lambs subjected to different feeding regimes. Semina: Ciências Agrárias, 37(2), 911-920. http://dx.doi.org/10.5433/1679-0359.2016v37n2p911

Sousa, D. L., Pimentel, P. G., Silva, E. M. C., Pereira, E. S., Montenegro, A. R., Campos, A. C. N., Mizubuti, I. Y., \& Santos, A. A. (2016). Meat quality of castrated and non-castrated Santa Ines lambs subjected to food restriction. Semina: Ciências Agrárias, 37(3), 1515-1526. http://dx.doi.org/10.5433/1679-0359.2016v37n3p1515

Statistical Analysis System Institute. (2001). SAS/STATS user's guide. Version 8.2. Cary: SAS Institute.

Stone, H., \& Sidel, J. L. (1998). Quantitative descriptive analysis: developments, applications and the future. Food Technology, $52,48-52$

Superintendência do Desenvolvimento do Nordeste - SUDENE. (2011). Polígono das secas. Recife. Retrieved in 2017, March 19, from http://redeacqua.com.br/2011/03/poligono-das-secas/

Verbeek, E., Waas, J. R., Mcleay, L., \& Matthews, L. R. (2011). Measurement of feeding motivation in sheep and the effects of food restriction. Applied Animal Behaviour Science, 132(3-4), 121-130. http://dx.doi.org/10.1016/j.applanim.2011.03.014

Zhao, J. X., Liu, X. D., Zhang, J. X., y, W., \& Li, H. Q. (2015). Effect of different dietary energy on collagen accumulation in skeletal muscle of ram lambs. Journal of Animal Science, 93(8), 4200-4210. PMid:26440200. http://dx.doi.org/10.2527/jas.20159131

Funding: Conselho Nacional de Desenvolvimento Científico e Tecnológico - CNPq (Beneficiário: Marta Suely Madruga), Brasil, projeto $n^{\circ} 441248 / 2017-9$. 